\title{
JAKOŚCIOWY ZWROT ROZWOJU POLSKICH SZKÓŁ - ASPEKT POSTULATYWNY
}

\section{QUALITATIVE TURN IN THE DEVELOPMENT OF POLISH SCHOOLS - A POSTULATED ASPECT}

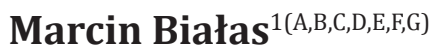 \\ ${ }^{1}$ Akademia Wychowania Fizycznego i Sportu im. Jędrzeja Śniadeckiego, \\ Wydział Rehabilitacji i Kinezjologii, Zakład Terapii Zajęciowej
}

\begin{abstract}
Białas, M. (2018). Jakościowy zwrot rozwoju polskich szkół - aspekt postulatywny. Rozprawy Społeczne, 12(1), 15-20. https://doi.org/10.29316/rs.2018.02
\end{abstract}

Wkład autorów:

A. Zaplanowanie badań

B. Zebranie danych

C. Dane - analiza i statystyki

D. Interpretacja danych

E. Przygotowanie artykułu

F. Wyszukiwanie i analiza

literatury

G. Zebranie funduszy

Tabele: 0

Ryciny: 0

Literatura: 12

Otrzymano: październik 2017

Zaakceptowano: listopad 2017

\section{Streszczenie}

Celem niniejszej pracy jest wskazanie propozycji jakościowych zmian, jakie winny nastąpić we współczesnych polskich szkołach. Przeciwstawiają się one traktowaniu uczniów w kategorii „biologizmu”, który warunkuje konieczność napełnienia ich wiedzą podawaną w postaci gotowej „pigułki”. Akcentując wolność uczniów do dokonywania własnych wyborów i ich gotowość do samorealizacji, propaguje zdobywanie wiedzy w sposób aktywny, twórczy, problemowy oraz przyjazny, ujmując uczniów jako suwerenów własnego rozwoju.

Słowa kluczowe: szkoła, reforma, zmiany jakościowe, wolność, suweren rozwoju

\section{Summary}

The aim of the present work is to indicate the qualitative proposals for changes to be made in the contemporary Polish schools. They oppose the "biologistic" approach to students, insisting on the need to fill them with knowledge in the form of a premade "pill". By emphasising the freedom of students to make their own choices and their readiness for self-realisation, it promotes the acquisition of knowledge in an active, creative, problem-oriented and friendly way, picturing students as sovereigns of own development.

Keywords: school, reform, qualitative changes, freedom, sovereign of development

\section{Społeczny kontekst funkcjonowania współcze- snej szkoły}

Wiek XXI to okres, na który składa się gigantyczny rozwój naukowo-techniczny, mający swoje zastosowanie w każdej dziedzinie ludzkiego życia, nastawiony na maksymalny wzrost gospodarczy, realizowany w warunkach potężnego rynku globalnego i zapewniający nieustanne zwiększenie ilości dóbr i usług konsumpcyjnych. Nakładająca się na ten obraz zauważalna niestabilność światowej gospodarki rynkowej czy też ponowne zagrożenie wielkimi kryzysami ekonomicznymi nieodzownie wiążą się z bezrobociem, a tym samym i niezadowoleniem społecznym, potęgując coraz bardziej widoczne rozwarstwienie społeczne oraz biedę. Niemały wpływ na dramaturgię współczesnego życia mają prowadzone na świecie konflikty zbrojne, realne zagrożenia nowymi wojnami, nasilające się i coraz bardziej śmiałe ataki terrorystyczne, czy problemy związa- ne coraz większą rzeszą napływających do Europy uchodźców etc. Wszystkie wymienione i im podobne składowe dokładnie nakreślają złożoną i zarazem niełatwą, niestabilną rzeczywistość. Nie jest ona obojętna nawet dla mało zaangażowanego w życie społeczno-polityczne, czy też ekonomiczne człowieka (Białas, 2015). Jej styl i jakość wpływają bowiem na myślenie i działanie każdego bez wyjątku człowieka, budując jego światopogląd, stawiając jednocześnie pojedynczych ludzi i całe społeczeństwa przed koniecznością nabywania nowych sposobów zachowania się i wartościowania. Wymaga to od pokolenia młodych dokonania zasadniczych zmian mentalnych i świadomościowych związanych z koniecznością wprowadzenia gruntownych zmian w ich edukacji.

Dlatego też i od współczesnej polskiej szkoły wymaga się wyedukowania nowego człowieka - „człowieka pełnomocnego - o ukształtowanych kompetencjach do formułowania i rozwiązywania nowych, trudnych zadań, mądrego, odpowiedzialnego, współ-

Adres korespondencyjny: Marcin Białas, Akademia Wychowania Fizycznego i Sportu im. Jędrzeja Śniadeckiego, Wydział Rehabilitacji i Kinezjologii, Zakład Terapii Zajęciowej, ul. Kazimierza Górskiego 1, 80-336 Gdańsk, e-mail: bialasmarcin@o2.pl, tel. 585547121

Copyright by: Państwowa Szkoła Wyższa im. Papieża Jana Pawła II w Białej Podlaskiej, Marcin Białas

Czasopismo Open Access, wszystkie artykuły udostępniane są na mocy licencji Creative Commons Uznanie autorstwa-użycie niekomercyjne-na tych samych warunkach 4.0 Międzynarodowe (CC BY-NC-SA 4.0, http://creativecommons.org/licenses/by-nc-sa/4.0/). 
czującego i zdolnego do solidarnego współdziałania, umiejącego krytycznie wybierać z wielorakich i migotliwych ofert kulturalnych i osadzać je wedle uniwersalnych wartości i zasad. Jeżeli edukację rozumieć jako ogół warunków, procesów i czynności sprzyjających optymalnemu i adekwatnemu rozwojowi osoby, to ukształtowanie wzoru człowieka na miarę złożonych wyzwań współczesności zależy właśnie od edukacji i to od edukacji powszechnej, masowej, dostępnej dla wszystkich warstw społecznych i dla każdego pokolenia" (Kwieciński,1999, s. 51). Przed współczesną polską szkołą stoją więc niezwykle pilne społecznie oczekiwania i zadania. Szkoła ma bowiem pomóc uczniom w rozumieniu coraz bardziej skomplikowanych realiów niestabilnego życia, nowych „zasad porządku” społecznego, gospodarczego i kulturalnego. Szkoła ma pomóc uczniowi zrozumieć świat. Eksplikacja tej tezy stanowi cel niniejszego pracowania.

\section{„Biologiczne” uwarunkowania edukacji uczniów}

Jakościowe zmiany wprowadzane we współczesnej polskiej szkole nakreślają jej nowe wizje, wyznaczają nowe misje i strategie działania. Opieraja się na nowej organizacji nauki szkolnej, zbudowanej na nowoczesnych programach edukacyjnych oraz podręcznikach. Zmianie ulegają także warunki lokalowe współczesnych polskich szkół, które stają się z roku na rok coraz ładniejsze, lepiej wyposażone, coraz bardziej nowoczesne.

Niestety, tym co pozostaje niezmienne, choć nigdy nie formułowane expresis verbis, jest przyjmowany „biologiczny model” postrzegania uczniów. Model ten zakłada patrzenie na ucznia jako osobę, którego rozwój intelektualny, determinowany biologicznie, przechodzi przez standardowy ciąg stadiów składających się na ścieżkę wiodącą ku pełni, ku dojrzałości. Postęp w tejże „wspinaczce” realizowany jest na kolejnych etapach edukacji szkolnej, co obrazowo wyraża metafora wchodzenia po drabinie. W przyjętym „biologicznym modelu” redukuje się obraz ucznia sprowadzając go do wymiaru braków i ograniczeń, oferując mu pomoc w transmisji wiedzy, niezbędnej do osiągniecia z góry przewidzianych celów. Uczeń, pokonując kolejne szczeble drabiny, absorbuje gotową wiedzę, przekazywaną przez nauczycieli, często w schematyczny, wyćwiczony w toku wieloletniej pracy zawodowej sposób (oparty na prostych zasadach, stałych odruchach i wyuczonych reakcjach). Uczestniczy w powierzchownym, ograniczonym ramami czasowymi i presją zrealizowania całości wyznaczonego materiału procesie edukacyjnym opartym na zbiorze przekonań autorów podręczników, przy wciąż jeszcze zatomizowanych przedmiotach nauczania. Praktyka takich działań nadal ogranicza się do podania uczniom wiedzy w postaci „pigułki”, której efekt działania podlega ścisłej kontroli (np. w postaci testów, sprawdzianów, egzaminów etc.) oraz wyłącznie ilościowej (najczęściej punktowej) interpretacji uzyskanych wyników. Uczniów bowiem „trzeba napełnić wiedzą, umiejętnościami i wartościami dominującymi w kulturze, które są z góry określone, społecznie usankcjonowane i gotowe do zaaplikowania, - co określa się jako proces reprodukcji lub transmisji oraz nauczyć ich podporządkowywania się sztywnym wymaganiom systemu obowiązkowej nauki szkolnej" (Dahlberg, Moss, Pence, 2007, s. 99).

W tym znaczeniu przyjęty „biologiczny” model postrzegania ucznia ukazuje proces edukacji jako narzędzie służące do przekazywania mu z góry ustalonego i niekwestionowanego zasobu wiedzy o już określonym znaczeniu. Nauka szkolna staje się zatem edukacją, w której wiedza jest darem ludzi, którzy uważają samych siebie za wiedzących lepiej od tych, których uważają za niewiedzących nic. W przyjętym „biologicznym modelu” postrzegania współczesnego ucznia, nauczyciele stają się „sprawnymi i wymagającymi technikami”. Wyposażeni w metodyczne umiejętności i techniki pracy, wspierani przez środki techniczne i elektroniczne pomoce naukowe, realizują swoje edukacyjne zadania. Wchodząc w rolę arbitrów, przyjmujących z zewnątrz sterowną, kierowniczą rolę, preferując percepcyjno-odtwórczy model prowadzenia lekcji stają się tym samym autorytetami mającymi uprzywilejowany głos.

Podczas schematycznie prowadzonej lekcji, mającej swój rozpisany scenariusz, zadają uczniom pytania wynikające z treści omówionego (przerobionego) materiału, oczekując od nich jedynie właściwych i precyzyjnych (ściśle określonych w przyjętym kluczu) odpowiedzi. Nauczyciele bowiem znają na nie „prawdziwe” odpowiedzi i tylko na takie czekają. W toku trwania lekcji nie ma zatem czasu na dyskusję, wymianę myśli czy argumentowanie odpowiedzi. Nauka szkolna traktowana jest w kategoriach fundamentu, niezbędnego w przyszłości. Dlatego też nauczyciele akcentują i doceniają wyłącznie te działania, które będą „się opłacać” w długoterminowej perspektywie, tym samym w istocie traktując swoich uczniów w sposób przedmiotowy, pozbawiając ich własnych pomysłów i możliwości, w zamian napełniając gotową wiedzą (Dahlberg, i in., 2007).

\section{Dysfunkcje i deficyty uczniów pryzmacie „biolo- gicznego modelu nauczania"}

Wspinaczka uczniów po szczeblach drabiny szkolnej nie jest zadaniem łatwym. W rzeczywistości tylko niewielka grupa zdolnych uczniów, choć raczej należałoby użyć słowa pilnych, z sukcesem pokonuje kolejne „szczeble drabiny”. Tę swoistą „elitę” stanowią uczniowie, którzy w sposób bardzo dobry 
opanowali zasady „wspinaczki” (grzeczni, ułożeni, zawsze przygotowani do zajęć). Stanowiąc niewątpliwą wizytówkę szkoły. zawyżają swoimi sukcesami rankingi najlepszych szkół, które dowodzą jednocześnie o sukcesach edukacyjnych zatrudnionych w nich nauczycieli (najlepsi uczniowie, najlepsi nauczyciele, najlepsza szkoła).

Pozostali to tzw. przeciętni (w zdecydowanej większości) i słabi uczniowie, którzy swoją „wspinaczkę" okupują wielkim wysiłkiem i zaangażowaniem także i innych osób bezpośrednio zaangażowanych w działania edukacyjne. $\mathrm{W}$ tym względzie wyjątkowe znaczenie przypisuje się w klasach młodszych rodzicom (zwłaszcza matkom), natomiast w starszych korepetytorom i innym specjalistom, terapeutom (np. psychologom). Ich praca i zaangażowanie wydają się być niezbędne dla uczniów, którzy nie są w stanie przyswoić bezpośrednio w szkole wymaganej „pigułki” wiedzy. Potrzebują zatem dodatkowych zajęć, które stanowią zazwyczaj podawaną indywidualnie, lub w mniejszych grupach kopię szkolnych lekcji. Uczniowie, którzy sobie nie radzą, nie są w stanie przyswoić proponowanej przez szkołę „pigułki” wiedzy lub zwyczajnie mają braki w wyniku jakiś zaniedbań, muszą poświęcać wiele czasu i wysiłku (poza nauką szkolną) na kolejne działania edukacyjno-wyrównawcze, nierzadko także i terapeutyczne (dodatkowe lekcje, korepetycje, sesje trwające nierzadko do późnych godzin nocnych). Wszystkie one mają za zadanie wyrównać braki i zbliżyć jak najbardziej uczestniczących w tychże dodatkowych zajęciach uczniów do granicy przyjętej normy ustanowionej wynikami klasowej „elity”. Uczniowie przeciętni, a zwłaszcza słabi, wymagają nierzadko permanentnie prowadzonych dodatkowych zajęć, przez co notorycznie (nierzadko przez cały okres nauki szkolnej) przeżywają sytuację swojego niepowodzenia. Wątpią w swoje możliwości intelektualne, stają się przez to osobami sfrustrowanymi, nieczerpiącymi żadnej przyjemności z wykonywania intelektualnych zadań szkolnych (Domagała-Zyśk, 2004).

Dzięki zinternalizowanemu porządkowi ideowemu, zawartemu w „biologicznym” postrzeganiu uczniów, co łączy się z koniecznością wyrównania braków, nadrobieniem materiału czy uzupełnieniem wiedzy, bazuje się na dramatycznym napięciu między ideą dobra, przypisaną działaniom edukacyjno-wyrównawczym i terapeutycznym, oraz zła obciążającego zaniedbanie. Siła oddziaływania tego schematu moralnego jest tak potężna, że nie pozwala dostrzec faktów, które wyraźnie wskazują na to, iż nie wszystkie działania w zamierzeniu dobre przynoszą oczekiwane efekty. Hiperaktywność edukacyjno-wyrównawcza i terapeutyczna uspakaja co prawda sumienia rodziców, ale skazując jednocze- śnie ich dzieci - uczniów na przeciążenia psychiczne i wynikające $\mathrm{z}$ nich zaburzenia w funkcjonowaniu (Krakowiak, 2003, s. 4). W rezultacie zostają one jeszcze bardziej pozbawione autonomii osobowej pod wpływem tychże "tyranicznych" - edukacyjno-wyrównawczych i terapeutycznych działań prowadzonych dla ich rzekomego dobra. Przemęczeni, często bez czasu wolnego dla siebie, przeznaczonego na odpoczynek, czy też kulturowy rozwój, nierzadko z poczuciem chronicznego braku sukcesu edukacyjnego, który jest przecież niezbędnym elementem dla ich prawidłowego rozwoju, zostają zmuszeni do „przedmiotowej tresury”, której celem (opłaconym nierzadko ponad ludzkim wysiłkiem oraz ponoszonymi kosztami finansowymi dodatkowych zajęć) jest gotowość wspięcia się na kolejny szczebel drabiny szkolnej.

\section{Współczesna szkoła szansą samorozwoju wolnych uczniów}

Sytuacja ekonomiczno-polityczna obserwowana na świecie, wyczuwalny klimat społecznych nastrojów czy też tempo współczesnego życia wymuszają konieczność „wykreowania” nowego człowieka rozumiejącego świat i procesy w nim rządzące. Takiego, który będzie mógł się rozwijać i osiągać zadowolenie we wszystkich aspektach swojego życia. Świadomego swojej wartości, w pełni korzystającego ze swojej wolności. „Nadszedł czas, aby zrozumieć, że świat będzie taki, jacy będą żyjący w nim ludzie. Zawiodły wszelkie próby odwrócenia tej zależności [...]. Okazało się, że każda próba zmieniania człowieka za niego, z zewnątrz obraca się przeciwko niemu i przeciwko tym, którzy usiłowali go zmienić” (Obuchowski, 1993, s. 40). Owo „wykreowanie” nowego człowieka nie może jednak odbywać się w sposób wymuszony, sztuczny, jednakowy dla wszystkich, niezgodny z jego wewnętrznymi przekonaniami, potrzebami i oczekiwaniami. To przecież sam człowiek „ponosi odpowiedzialność za swój rozwój, za umiejętność rozwiązywania różnorodnych problemów, także życiowych, sposób doświadczania świata, odbiór wrażeń i kondycję własnej świadomości, za umiejętność odnoszenia sukcesów i unikania porażek, pokonywania sytuacji krytycznych i nadawanie sensu (własnemu życiu)" (Kargulowa, 2009, s. 8).

Jeżeli przyjąć powyżej nakreślone słowa za istotne, wydaje się zatem nieodzowne, aby przyświecały one zmianom jakie dokonują się w polskich szkołach. Nikt nie zaprzeczy, że kierunek aktualnie obranych zmian i reform jest słuszny. W praktyce wydaje się on jednak być jedynie fasadowym. Proponowane zmiany nie dotykają bowiem istoty problemów z jakimi winna się zmierzyć, jakim winna sprostać polska szkoła na miarę XXI w. Wydaje się zatem, iż: 
- po pierwsze, aby szkoła pomogła zrozumieć współczesny świat, musi zacząć szanować wolność swoich uczniów, stanowiącą wyróżnik ich człowieczeństwa, rozumianą jako zasadniczą zdolność (faculty, capacity) do spełniania aktów wolnych, stanowiących fundament ich samorealizacji (Seifert, 1997). Wydaje się zatem, że owo otwarcie się na podmiotową wolność uczniów winno stanowić istotę współczesnej szkoły, w której uczeń postrzegany jest $w$ kategoriach suwerena własnego ciała, rozumu, emocji i woli - suwerena samego siebie i własnego życia, jawiąc się przy tym jako przeciwstawna forma traktowania go (jak dotychczas) w kategoriach „biologizmu” i jego uwarunkowań, tzn. braków i ograniczeń, które wypełniał nauczyciel podając gotową „pigułkę” wiedzy. Wydaje się zatem, że wyakcentowanie wolności w edukacji, przy jednoczesnym traktowaniu ucznia w kategorii suwerena własnego rozwoju, umożliwi mu bowiem w sposób wolny (dowolny, indywidualny do potrzeb ucznia) indywidualizację celów, różnicowanie treści, dostosowanie tempa nauczania oraz spersonalizowanie metod, środków i ich form jego nauczania. Niewątpliwie przełoży się to na jego indywidualny sukces edukacyjny;

- po drugie, przygotowanie uczniów do rozumienia świata poprzez ich edukację, winno odbywać się w sposób przyjazny, rozumiany zarówno w kategoriach panującej w szkole atmosfery, jak i sposobów nauczania. Implantacja takiego sposobu pojmowania szkoły, patrzenia na procesy edukacji i uczniów, nawiązują zarówno do pierwotnego (etymologicznego) pojmowania szkoły, której grecki rzeczownik schole oznaczał właśnie czas wolny, oraz scholastikos rozumianej jako osoba spędzająca czas wolny, zwłaszcza na nauce. Pierwotnie bowiem szkoła nie kojarzyła się z wysiłkiem umysłowym, lecz relaksem, rozluźnieniem, miłym spędzaniem wolnego czasu. w myśl zasady głoszącej, iż osoby uczące się pod przymusem i w stresie osiągają słabsze wyniki (co potwierdza także i współczesna biologia mózgu). Uczeń, który jest zrelaksowany i odprężony, lepiej wykorzystuje swój potencjał, a także optymalnie wspomaga proces zdobywania wiedzy (wiedzieli już o tym starożytni) (Kwieciński, 1999). W praktyce nie oznacza to odejścia od konieczności przekazania uczniom faktów, niezależnych od ich doświadczenia, istniejących w kulturowej, instytucjonalnej czy historycznej próżni, a jedynie wystrzegania się społecznie konstruowanej natury wiedzy w postaci „pigułki”, przekazywanej w pośpieszny, mało precyzyjny (bez połączenia z uprzednio już zdobytą wiedzą) i nierzadko w chaotyczny sposób przy szczególnym akcentowaniu twórczych - problemowych sposobów nabywania przez uczniów wiedzy (Dahlberg i in., 2007). Wiadomościom szkolnym brakuje bowiem owego ujęcia strukturalno-problemowego, które torowałoby drogę integracji wiedzy w umyśle ucznia. Ten jak to nazwano, powszechnie i wciąż jeszcze stosowany encyklopedyzm godzi bowiem nie tylko $\mathrm{w}$ indywidualną potrzebę rozumienia, ale także $\mathrm{w}$ potrzeby rozwijającego się społeczeństwa. Ponieważ przyszłość jest zasadniczo nieprzewidywalna, szkoła zatem powinna przygotować uczniów do roli „nowatorów" (Konarzewski, 1999);

- po trzecie, w tym aspekcie wydają się być niezmiernie ważne również zmiany w sposobach realizowania treści zawartych w programach nauczania. Winny one być jak najbardziej połączone z życiem codziennym uczniów, nastawione na ukształtowanie wiedzy, umiejętności i kompetencji społecznych, w oparciu o krytyczne myślenie i samodzielne do nich dochodzenie. $\mathrm{W}$ tym rozumieniu działania edukacyjne winny zatem przybierać formę problemową, odwołującą się do krytycznych i żywych zainteresowań uczniów, bazującą na ich zdolnościach, wrażliwości, wyobraźni oraz umiejętności współżycia i współdziałania z ludźmi w celu rozwiazywania stawianych przez szkołę (edukacyjnych) sytuacji problemowych. W tym znaczeniu sytuacją problemową dla ucznia może być bowiem każda sytuacja zarówno materialna jak i duchowa (każda treść, każde zagadnienie lekcyjne czy zadanie). Ważne jest, aby taka sytuacja wzbudziła jego aktywności, zachęcając go jednocześnie do odpowiedniej zmiany w taki czy inny sposób. Stąd też zajęcia lekcyjne winny być utożsamiane ze stanami rodzącymi takie właśnie sytuacje problemowe przy założeniu, że ich rozwiązanie jest dla ucznia wyłącznie skutkiem jego własnej aktywności, która stawia go przed koniecznością znalezienia odpowiedniego kierunku, sposobu działania, środków, czyli stawia go przed problemem. Może w nim chodzić o znalezienie lub wytworzenie przedmiotu, zbudowanie prototypu, opracowanie i zrealizowanie projektu, przeprowadzenie wywiadu, obserwacji, namalowaniu 
plakatu, czy wreszcie o wymyślenie nowej lub obronę przyjętej idei etc. Zajęcia lekcyjne prowadzone w oparciu o sytuacje problemowe niewątpliwie zaktywizują uczniów, którzy osobiście zaangażowani w proces dochodzenia do wiedzy lepiej się uczą. Stopień zaś emocjonalnego zaangażowania w „zmianę jakiejś sytuacji” jest miarą problemowości tejże sytuacji dla ucznia - podmiotu oddziaływania edukacyjnego (Cackowski,1979);

- po czwarte, zaproponowane zmiany winny również dotyczyć nauczycieli. Ogromną rolę w samorozwoju ucznia odgrywają umiejętności aktualizacji i wykorzystania własnych, wrodzonych potencji intelektualnych czy wolicjonalnych, które niekiedy jeszcze nie uświadomione winny być odkryte we współpracy z nauczycielem (Kozielski, 1999). Dlatego też nauczyciele podczas zajęć lekcyjnych winni nastawić się na formowanie przez uczniów własnych (nierzadko krytycznych) sądów, własnego spojrzenia na otaczający świat, autorsko przedstawioną analizowaną sytuację po to, aby pielęgnować u swoich uczniów ich autonomię, by niczego im nie narzucać, nie rozstrzygać za nich. Uczyć ich krytycyzmu i kryteriów ocen według uniwersalnych wartości kultury, nie używając i nie nadużywając władzy i autorytetu przydanego nauczycielom z racji pełnionych przez nich funkcji (Kwieciński, 1999). Dlatego też współczesna szkoła potrzebuje nauczycieli o nowych kwalifikacjach, z otwartymi kompetencjami i innowacyjnych. Nauczycieli, którzy poprzez stwarzanie możliwości i szans, które powodują otwarcie się na nowe znaczenia i nowy sposób doświadczania, dadzą uczniom możliwości do samorozwoju, umożliwiając im posługiwanie się własnym rozumem i wolą w zdobywaniu i przyswajaniu wiedzy. Wykształcenie nauczycieli nie może ograniczać się zatem do wiedzy z zakresu prowadzonego przedmiotu i metodyki jego nauczania. Nauczyciele powinni być kształceni na tyle szeroko, aby ich wiedza i umiejętności dawały możliwość sprostania nowym oczekiwaniom uczniów - jako suwerenów własnego rozwoju. Muszą oni stać się organizatorami nie lekcji, lecz spotkań edukacyjnych. Z szacunkiem przyjmując punkty widzenia poszczególnych uczniów, prowokując konflikty poznawcze, stosując specyficzne strategie edukacyjne wychodzące nierzadko poza dostarczone informacje, by w konsekwencji doprowadzić do zbudowania pojęciowo spójnych teorii w myśleniu i rozumowaniu swoich uczniów jawiąc się przy tym jako szczególni partnerzy w uczeniu się uczniów, nie narzucający im treści, nie zmykający horyzontów, ale współuczestniczący w odkrywaniu nowych znaczeń i mobilizujący do samodzielności. Będąc przewodnikami uczenia się, w poszukiwaniu przez uczniów wiedzy, organizowaniu jej i posługiwaniu się nią dostarczają intelektualnych drogowskazów, które pozwalają uczniom zrozumieć świat i czuć się jego odpowiedzialnymi uczestnikami. Budując rusztowanie dla ich myślenia i działania, poprzez negocjowanie znaczeń spowoduje głębokie i zrazem interdyscyplinarne „zanurzenie się" w omawianym zagadnieniu.

Nakreślona powyżej propozycja zmian nie wymaga nakładów finansowych. Nie wymaga tworzenia nowych specjalistycznych pracowni, zakupu nowego sprzętu, czy skomplikowanych urządzeń. Bazuje bowiem na tym co jest, traktując zaistniały kapitał (materialny i intelektualny) jako podstawę do wprowadzenia zmian. Potrzeba jedynie zmian jakościowych, wymagających nowego spojrzenia na szkołę i na jej nadrzędny cel, nowego spojrzenia na pracę nauczycieli i nowych sposobów realizacji treści nauczania. Wymaga również nowego spojrzenia na uczniów jako suwerenów własnego rozwoju.

Wydaje się zatem, że ten nowy w znaczeniu jakościowo odmienny sposób patrzenia na szkołę sprawi, że uczniowie staną się w coraz większym stopniu odpowiedzialni za formowanie i kształtowanie własnego rozumienia świata, wiedzy, a także tożsamości i stylu życia. Ten proces ich indywidualizacji oznacza bowiem w coraz większym stopniu samodzielne kontrolowanie przez nich swoich wyborów i działań oraz kierowanie nimi w sposób indywidualny i wespół z innymi uczniami. Współczesna szkoła winna bowiem stać się przestrzenią, w której możliwe będzie badanie i realizowanie nowych możliwości, poprzez poszerzenie refleksyjnych i krytycznych sposobów poznawania wiedzy. Gdzie jej konstruowanie, a nie odtwarzanie, umożliwi uczniom twórcze działania, przez co przyczyniać się będzie do urzeczywistnienia ich twórczych możliwości przy równoczesnym, stopniowym wyłanianiu się pluralistycznej mozaiki współczesnych poglądów na świat i życiowych eksperymentów. Gdzie wiedza, tożsamość, kultura są wytwarzane i przetwarzane w stosunkach z innymi - są współkonstruowane (Dahlberg, i in., 2007). Umysły uczniów osiągną bowiem pełną wolność nie przez gromadzenie wiedzy i idei innych ludzi, ale przez wytwarzanie własnych standardów i opinii oraz własnych myśli (Nussbaum, 2013). 


\section{Literatura:}

1. Białas, M. (red). (2015). Świat dziecka zagubionego w społeczeństwie. Poznań: Wydawnictwo Naukowe Wyższej Szkoły Pedagogiki i Administracji im. Mieszka I w Poznaniu.

2. Cackowski, Z. (1979). Człowiek jako podmiot działania praktycznego i poznawczego. Warszawa: Wyd. Książka i Wiedza.

3. Dahlberg, G., Moss, P., Pence, A. (2007). Poza dyskursem jakości w instytucjach wczesnej edukacji i opieki. Wrocław: Wydawnictwo Naukowe Dolnośląskiej Szkoły Wyższej.

4. Domagała-Zyśk, E. (2004). Autonomia czy odłączenie? Rola osoby znaczącej w życiu młodzieży z trudnościami w nauce. Lublin: Wyd. KUL.

5. Kargulowa, A. (red.). (2009). Poradoznawstwo - kontynuacja dyskursu. Warszawa: Wyd. PWN.

6. Konarzewski, K. (1999). Reforma oświaty przedmiotem dyskursu. W: J. Kozielski (red.), Humanistyka przełomu wieków (s. 78-102). Warszawa: Wydawnictwo Akademickie „Żak”.

7. Kozielski, J. (1999). Zaduma nad możliwością ulepszenia człowieka. W: J. Kozielski (red.), Humanistyka przełomu wieków (s. 115-127). Warszawa: Wydawnictwo Akademickie „Żak”.

8. Krakowiak, K. (2003). Kim jest moje niesłyszq̨ce dziecko? Lublin: Wyd. GAUDIUM.

9. Kwieciński, Z. (1999). Edukacja wobec nadziei i zagrożeń współczesności. W: J. Kozielski (red.), Humanistyka przełomu wieków (s. 51-77). Warszawa: Wydawnictwo Akademickie „Żak”.

10. Nussbaum, M. (2013). Kształcenie dla zysku, kształcenie dla wolności. W: B.D. Gołębniak (red.), Pytanie o szkołę wyższa. W trosce o człowieczeństwo (s. 76-88). Wrocław: Wydawnictwo Naukowe Dolnośląskiej Szkoły Wyższej.

11. Obuchowski, K. (1993). Człowiek intencjonalny. Warszawa: Wyd. PWN.

12. Seifert, J. (1997). Być osobą - być wolnym. W: Z. Zdybicka, J. Herbut, A. Maryniarczyk, A. Łyskawka, N. Szutta (red.), Wolność we współczesnej kulturze (s. 157-115). Lublin: Wyd. KUL. 